\title{
\&s \\ THE "PRIMER ENTREMES DE SELESTINA": \\ AN EDITION, WITH AN INTRODUCTION, NOTES AND \\ A READING TEXT OF AN ANONYMOUS CELESTINESQUE WORK OF THE SIXTEENTH CENTURY
}

IVY A. CORFIS

University of Michigan

The vast popularity and dissemination of the fifteenth-century Spanish masterpiece, Celestina, is well-known and documented. The investigations of Menéndez y. Pelayo, Lida, Heugas, Chevalier and other critics have shed much light on the subject. ${ }^{1}$ However, the extent to which and exactly how Celestina influenced literature is still not completely understood, for there are yet many unedited celestinesque works, especially of the género chico: One such example of a little-known piece based on Celestina is the anonymous Bimer entremés de Selestina, located in the Biblioteca Nacional de Madrid, Ms. $14.612(9) .2$

The Entremes has five characters: Selestina; the student--who is her client; a bobo, doña María and Ynés, three members of Selestina's house. ${ }^{3}$ The plot is straightforward and centers around the student's efforts to enter Selestina's house in order to pay a visit to his lover, Ynés. Aithough Selestina has refused to admit the student because he has no money, he uses a simple deception to lure Selestina (and also doña María) away and to thus prepare his own entrance into the unguarded house.

The Entremes begins with a long opening speech to the audience, delivered by Selestina, in which she tells of the-nature of her profession. In her descripction are several trades she plies, all of which are standard in celestinesque works after Celestina. Selestina proceeds to classify herself as "mother" and procuress of "cousins" and go-betweens--all working for a price, of course. She is mender of virgins; sorceress; provider of materials needed for the magic arts; reuniter of lovers--even from distant lands by means of magic--; friend of gallants and ladies, of drink, and of money. Her businesses offer something for everyone, and provide exactly what the customer orders: virgin, unmarried or widowed women.

In contrast to the original Celestina, the entire Entremes has a marked comic tone, and the characters have become mere types in the service of a burlesque plot and jokes. The student is poor and crafty; Selestina is money-hungry; the bobo is greedy and gullible and Ynés, young and in love. Doña María appears briefly and is not fleshed out even in terms of a broad character type. 
The Entremes has also departed from the origina1 in that the alcahueta is outwitted by the client, having failed to reflect the astute cunning and wile with which Celestina was endowed. The student best manipulates the situation, and achieves his purposes in the end. What does remain of the original work, besides the character types (Selestina, her niñas, and clients) and setting (brothe1), 4 are reminiscences of Celestina's language. For example, Celestina is recalled in this passage from the Entremés (11. 17-17):

$$
\begin{aligned}
& \text { Selestina: ... tanto valen tres vezes de vino como } \\
& \text { tres años de estudio, como en mi ystoria } \\
& \text { más largamente se lee. }
\end{aligned}
$$

Here the text is reminiscent of this passage from an interpolation in Act IX of the Tragicomedia:

\author{
Pármeno: Madre, pues tres vezes dizen que es bueno \\ e honesto todos los que escriuieron.
}

Celestina: Hijos, estará corrupta la letra; por treze, tres.5

As Menéndez Pidal pointed out, the phrase, as a popular proverb, was repeated in other works influenced by Celestina: e.g., Aqui comiençan unos vilzancicos muy graciosos de vnas comadres muy amigas del vino and La Zozana andaZuza. 6

Linguistically, the Entremes shows marked influence of seseo and imitation of the actual speech of the lower-class environmenc it portrays. The text norm establishes by a margin of 4 to 1 the use of the symbol $s$ for what would ordinarily be $z$ or $\xi:$ that is, $/ \mathrm{s} /$ for $/ \hat{s} /$ or $/ \hat{z} /$. Although many times in fifteenth-and early sixteenth-century script the sigma. very closely resembles the $z$ and poses difficulties in transcription, the $E n$ tremés hand presents no such confusion. The $z$ is clearly differentiated from the $s$, and the $s$ in the words under question is identical to all other appearances of the symbol s. For example, in the word suficientes, which is spelled sufisientes in the Entremés (1.10), all three $s$ 's are identical. If one were actually a $z$ resembling an $s$, it is undifferentiated from the others. Moreover, there are instances of the $z$ symbol in the text: e.g., haze (1. 3) and donzella (11. 21, 22). Since there is no other. evidence of the scribe ever using two symbols for the same letter, there is no reason to suspect the scribe used two $z$ symbols. Thus, the $z$, as found in the manuscript, is clearly distinguished from the $s$, and the use of $s$ for $z$ is not the result of careless transcription, but is rather the deliberate practice of the scribe.

The only exceptions to the $s$ for $z$ standard are the words alguazil, hazer, hechizo, donzella, gozar, and plazer, where the $z$ is included. vezes and casada are each used twice in the work and demonstrate the equivalent pronunciation of the two symbols $z$ and $s$, for the words are spelled both ways: vezes and veses; cazada and casada. The latter is especially significant since the context does not suggest the word cazada ('hunted'), but rather casada ('married'). 7 Thus, the $z$ symbol represents an /s/ sound. 
The abundant occurrence of the graphic $s$ for $z$, the interchange of $z$ and $s$ symbols, and the $z$ respresenting $/ \mathrm{s} /$, all point to an identical pronunciation of $z$ and $s$ as $/ \mathrm{s} /$; that is, speech marked by a clear seseo.

The language of the text reflects a low style and vocabulary typical of the social class of mufianes, alcahuetas, and rameras. The orthography imitates the pronunciation of the popular speech in various ways: 8

a. the elision and apocopation of words. in frequent, popular expressions ;

b. archaic verb forms;

c. relaxation and disappearance of /d/ in final position;

d. Vacillation between vowels--a phenomenon common in the period: between $i$ and $e$ (siguros for seguros) and $o$ and $u$ : (mormoráis for murmuráis);

e. a confusion of $h$ and $j$ in three cases: hihas, bruhas, and juyáis for hijas, brujas, and huyáis. The interchange would indicate that the $/ z /$ and $/ s /$ sound represented by the symbols $x$ and $j$ or $g$ were being relaxed and articulated farther back in the velar region. As the velar fricative $/ x /$ became aspirated in some regions, there arose the possibility of confusing the aspirated /h/ sound with the progressively more velar $/ x /$. In the three instances in the Entremés, the written text projects the spoken confusion of $h$ and $j$, mainly associated also with the lower classes.

Thus, the Primer entremés de Selestina is of interest not only as an example of Celestina's influence on sixteenth-century literature, but also as a linguistic document. The language of the Entremés may reflect the anonymous author's own speech or be a literary reconstruction of a dialect, but, regardless of the source, in various areas of sound and form, the language is consonant with the level and style of the social class of the characters portrayed.

In short, the Entremés has used Celestina to create an amusing farse. However, while the basic outline of Celestina remains, the deep, human appeal of the original has been sacrificed to fit the purpose of an entremés: to entertain the audience with light-hearted, comic relief. To achieve this end, the work combined lower-class jocularity and appropriate language, even as it drew on public recognition of a well-known literary mode1.

\section{EDITORIAL STANDARDS :}

I have transcribed the text as carefully as possible, retaining all the original orthography. The abbreviations have been resolved; letters added have been italicized. The only three abbreviations found in the manu script are: $\bar{q}=$ que; $\sigma=q u e ;$ and $\overline{r a}=$ vuestra. The $\forall$ has been trans cribed as $r p$ in all cases. 
Square brackets indicate changes in folios and columns and set off stage directions. The latter bracketing replaces the manuscript convention of a horizontal line above and below, or a rectangular box surrounding, the stage directions.

I have modernized capitalization and punctuation. The only punctuation found in the original text is a slash (/) which generally corresponds to a modern period. An apostrophe indicates synaloepha and separates two words spelled as one in the original. In such cases, the manuscript spel1ing is given and explained in the notes to the text.

\section{NOTES TO THE INTRODUCTION}

1 The bibliography on Celestina is extensive, and some investigation has been done on many other works, authors, and genres influenced by Celestina. Mention may be made of such works on the subject as those by Marcelino Menéndez y Pelayo, Orígenes de la novela, III (Madrid: NBAE, 14, 1910); María Rosa Lida de Malkiel, La originalidad artística de 'La Celestina'(Buenos Aires: Edit. Universitaria, 1962; 2nd ed., 1970); Pierre Heugas, 'La Célestine' et: sa descendance.directe (Bordeaux: Institut... d'Etudes Ibériques et Ibéro-Americaines, 1973); Maxime Chevalier, 'La Ceiestina' según sus lectores." Lectura y lectores en la España del siglo XVI y XVII (Madrid:- Ed. Turner, 1976), pp. 138-166; and more recently, Keith" Whinnom; "The Problem of the 'Best-Seller' in Spanish Golden-Age Literature," BuZletin of Hispanic Studies, 57 (1980), 189-198.

2 The Primer entremés is third of eighteen entremeses and Zoas in the collection Entremeses incompletos: papeles sueltos de varias obras dramáticas, compiled 24 September 1862 and held in the Biblioteca Nacional de Madrid, Ms 14.612 (9). The Entremes is a pliego suelto (40, n.d.), whose first leaf contains the Entremes; the second leaf is left blank. The quarto measures $213 \times 152 \mathrm{~mm}$., and the script is arranged in two columns. The hand seems to be of the early sixteenth century. No watermark is present.

3 I shall use the Entremes spelling, Selestina, in order clearly to separate references to Rojas' creation, whose name shall be spelled in the traditional manner, Celestina.

4 The reference to Salamanca $(1.23)$ is also reminiscent of Celestina (although Salamanca is not mentioned in Celestina, many theories have been put forth regarding the exact identity of the unnamed city described by Rojas. For theories advocating Salamanca, see: José Ramos Jiménez, "Algo más que tenerías." Algunas notas en tomo a la Zocalización de 'La Celestina' (Salamanca: Trabajos y Días, 1950); Federico Romero, Salamanca, teatro de La Celestina': Con algunos apuntamientos sobre $l_{a}$ identidad de sus autores (Madrid: Escelicer, 1959); Manuel Criado de Val, "La celestinesca," Teoría de Castilla Za Nueva (Madrid: Gredos, 1960), pp. 308-330; and idem., "Si- 
guiendo a la Celestina," Campo Ziterario de Castilla Za Nueva (Madrid: Publicaciones Españolas, 1963), pp. 45-47.

5 For further identification of the refrán involved, see NOTES TO THE TEXT, no. 16 .

6 Ramón Menéndez Pidal, "Una nota a 'La Celestina'," Revista de filología española, 4 (1917), 50-51.

7 Entremes, line 22.

8

The NOTES TO THE TEXT give more explanation and examples of the 1inguistic phenomena here described briefly.
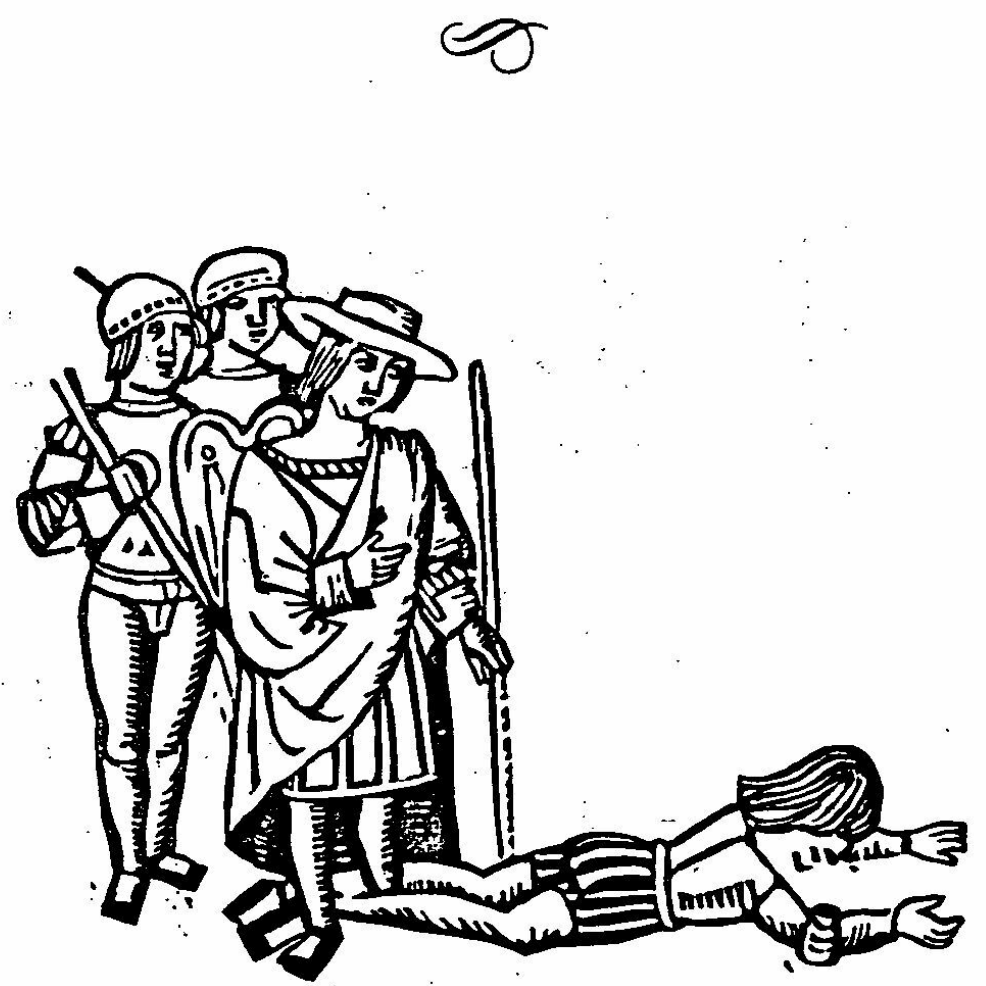

Calisto despeñado (Cover from Teatro Medieval, ed. Manuel Criado de Val). 
PRIMER ENTREMES DE SELESTINA: ${ }^{1}$ DOS DAMAS, VN VILLANO, VN ALGUAZIL, VN CORCHETE $^{2}$ [f. Ir, COl. A]

Se. Ya hihas ${ }^{3}$ de mi alma, si mi demasiada edad $n^{1}$ os $^{4}$ haze desconoserme me tendréys conosida y por sino lo soi. Yo soi aquella que di lus a primas y

5 a terseras: a primas de aprovechamiento, a terseras de 1 a consonansia ${ }^{5}$ que an de azer entre la prima y la parte para dar provecho y no quedar sin paga. Y soi aquella que en esta vid'a ${ }^{6}$ serrado cuatrosientos y seis portillos que por contrarios an sido enalmagrados. 7 Y soi aquella que a chupa$\operatorname{deras}^{8} q u^{\prime} e l$ bulgo 11 ama bruhas 9 a dado yngüentes ${ }^{10} \mathrm{y}$ unsiones . sufisientes

10 a su arte. Y soi aquella de quien amantes avsentes no an bibido siguros 11 de verse con sus damas traýdos de lexas tierras en breve espasio mediante el arte del hechizo, de cuya abilidad e 11 evado cátredal2 tres veses. Ya sé lo que mormuráis:13 diréis agora que la justisia botó por mí y el berdugo sicutólo14 botada, pues esas cátredas quiero qu'ell catredático, si no

15 sale por la calle, cuatro lo saben y ocho lo ynoran. 15 Yo soi querida de damas y galanes. Soi lus y lunbre del beber porque tanto valen tres vezes de vino como tres años de estudio, 16 [col. b] como en mi ystoria 17 más : largamente se lee. Sobre todo soi amiga de no estar sin tributo porque después que de mío lo perdí, me arrimo a dos niñas que me lo dan conforme al

20 que pide. Tengo en mis niñas toda mercaduría: al que pide donzella, se la doi donzella; y al que casada, la doi cazada; y biuda, al que biuda quiere. Huyo d'estudiantes porque soi natural de Salamanca y conóscolos desde mi niñés, y sólo os encarga bobas. Que juyáis 18 dellos que son ave de -rrapiña, secos como esparto, 19. pues con conosellos yo no me puedo librar de vno

25 que me persige ${ }^{20}$ vna de mis niñas y. la tiene engañada con villetes en copla y rramilletes de a dis ${ }^{21}$ maravedís. ¡Desventurada yo!, que avn aquí no me puedo librar dél.

[Sale el estudiante.]

Es. Norabuena ${ }^{22}$ vea yo a mi madre.

30 Se. ¿Yo tu madre? ¿Cuándo te parí?

Es. Que todavía me eres contraria.

Se. Que todavía no tienes dineros; nunca 1lega tu rrecuero. 23 Sierra esa puerta.

35 y para mí solo serrada, pues por vida de quien soi?

Es. ¿No es cosa del diablo ésta que para todos esté tu puerta abierta,

Se. No, como sé fieros. 24 [ Vase./ [fol. 1v, col. a.]

Es. Us 25 vais y cus ${ }^{26}$ que no va ni viene que no seré yo el lisensiado Lidon sin'os 27 hago vna ${ }^{28}$ que se ponga en el libro de la fama ansí, se-

40. ñora Selestina.

$$
\text { [ Sale el villano.] }
$$

Bo. Que os digo estodiante $\mathrm{e}^{29}$ que dis ${ }^{30} \mathrm{mi}$ ama que os vais a espetar ${ }^{31}$ a donde os pelaron, 32 que acá no ai espetadero.

Es. ¡O ermano Lucas!, seáis bienvenido. Abrásame. 
Bo. No; no; iaparta! iaparta!, que olé1s a pobre.

Es. ¿No es cosa del diablo ésta que todos los desta casa están fundados sobre ynterés?

Bo. No; no: a Ynés no la veréis, más aporreándola quedan.

Es. AAporreando! Ven $\mathbf{r}^{33}$ acá, Lorenso. ${ }^{34}$ Son éstos dinérós.

[ Vha mano con otra haze que suena dineros.]

Bo. S1, par Dios, dineros son. iSeñora! iSeñora!

Es. No; no la llaméis que yo no los quiero sino para vos si hazéis lo que us diré.

Bo. Como vos me lo déis, yo treparé.

Es. Pues mira que os atan fásil. Con sólo qüe le déis esta sédula a vuestra ama y ésta a doña María, os daré este dinero.

Bo. Y a Ynés, ino le e de dar nada?

Es. No, a Ynés, no. Ni avn a de ver éstas.

Bo. Dorabuena; ${ }^{35}$ vna a mi ama y otra a doña María. Aguarda [Vase.] $[\operatorname{col} . \mathrm{b}]$

Es. Esto va bueno; bien mi vengansa se enderesa que lo que éste ileva es vna esdropelia36 qu'el que la tuviere no parara ora ni momento en casa; y v́na ves está fuera, yo podré gozar de la mercadurla mejor que ésta vende.

$\left[\mathrm{Sale}^{37}\right.$ Selestina, el manto cubijada, 38 y doña María con el manto que se quiere cubixar y nunca asierta, disiendo: 7

Se. Dacá mi manto. 39

Ma. No puedo estar enserrada tanto.

Se. Dacá mi manto.

$M^{a}$. No puedo estar enserrada tanto.

Es. Bueno va esto; vengándome vo.

[Sale el bobo.]

Bo. ¿Que es esto? Sosegá. Serrado está. Ve aý su manto.

[Sale la otra dama que es Ynés.]

Yn. M1 lisensiado, norabuena te vea yo. ¿Qué es esto que tiene mi madre y mi ermana?

Es. No es nada, mi bien; que es vna esdropella que e hecho para que tu madre no me estorve el verte.

Bo. Sosegá, diablos; estáis borrachas.

Yn. Pues, ¿cóme 40 se puede quitar esto? 
Es. Con sólo quitalles aquel papel que tienen en la mano.

80 Yn. Pues si es tan fásil, ven; merendaremos entretanto.

Bo. Que le digo, deme aquel dinero.

Es. Que me plaze, mas primero quiero que me guardéis esta puerta: tené estos papeles en la mano, y éste guardaldo 41 aquí en el pecho que luego salgo.

[Vanse con 1 la dama. $]^{42}$

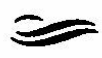

NOTES TO THE TEXT

1 The list of characters given in the title are dos damas, vn vilzano, un alguazil, vn corchete. The damas are doña María and Ynés; and the viZlano Lucas / Lorenso. However, while the corchete could possibly refer to the student, the Licenciado Lidon, there is still one character listed who does not appear in the text.

2 Corchete. According to the Diccionario de Autoridades (=Dicc. Aut.) II (Madrid: Gredos, facsimile of 1726 ed.), pp. 591b-592a, corchete is "especie de broche compuesto de macho y hembra, que se hace ordinariamente de alambre, y su uso es para. abrochar algúna cosa. A la hembra llamam regularmente Corchéta." And. "por alusion se le daba este nombre antes à ciertos Ministros que tenían los Alguacíles para llevar agarrados à los presos y deliquientes: y oy llaman assi à los Portéros de los Alcaldes."

3 Hihas. Hihas, as it appears in the manuscript, for hijas. The confusion of $h$ and $j$ is discussed by Rafael Lapesa, Historia de la lengua española, 8th ed. (Madrid: Gredos, 1980), pp. 379-380: "En las regiones donde se conservaba $1 \mathrm{a} / \mathrm{h} /$ aspirada procedente de /f-/ latina y de aspiradas árabes, la fricativa velar /x/ resultante de / $/$ / y / $/$ / se hizo también aspirada, confundiéndose con aquélla. Los primeros testimonios de $h$ por $g$ o $j$ parecen denunciar baja extracción social: en el Cancionero de obras de burlas (1519) se describe a una ramera como "de pequeña edad y hentil dispusición"; (...) A principios del siglo XVII el Buscón de Quevedo recibe el siguiente consejo sobre el habla del hampa sevillana: "Haga vucé cuando hablare de las $g, h$, y de las $h, g$; diga conmigo gerida ('herida'), mogino ('mohíno'), jumo, paheria, mohar, habali y harro de vino."

${ }^{4} \mathrm{~N}$ 'os. Nos, as in the manuscript, appears to be a synaloepha of not os. The same synaloepha occurs in the Cárcel de amor, Sevilla 1492: nos maravizléys for no os maravizzéys (f. $\mathrm{D}^{5} \mathrm{v}$. ).

5 The use of primas, terseras, and consonansia may also allude to musical terminology and be a play on words. a (ha).

$6 V_{i d} a$. Vida, the manuscript reading, seems a synaloepha of $v i d a+$ 
7 Enalmagrados (from almagrar / enalmagrar). According to Dicc. Aut. I, p. 225a: "Lo que está teñido con almágra. Lat. Rubricatus, $a$, um." And "jocosa y burlescamente se dice de aquel que ha salído de alguna pendéncia ò por otro accidente herído, ú descalabrado: y viene de la semejanza que tiene en el colór la almágra con la sangre. Lat. Suo ipsus fluente cruore rubricatus, a, um."

8 Chupaderas. The Dicc. Aut., II, p. 338b, gives the meaning of chupadera as "lo que saca $e_{1}$ xugo, ò lo húmedo de otra cosa que le tiene. Lat. Absorbens, -tis." However, the word could also be derived from the figurative meaning of chupar: "Metaphoricamente vale quitar suavemente con pretextos, engaños y lisonjas à uno lo que tiene, consumiéndoselo poco à poco y sin sentir. Lat. Sanguinem mursupii alicui exsugere. TORR. Philos. Lib. 5 cap. 7. De unos oirá que le chupan la hacienda" (II, p. 339a). Given our context, it seems obvious that the meaning of chupadera derives from its figurative meaning: one who, for a price, deceives.

9 Bruhas. This is the manuscript reading; for brujas or bruxas, as it appears in Celestina ( $i$ Burgos 1499?, as reproduced in facsimile by the Hispanic Society of America, New York, 1970; first printing, 1909), f. f6, 1. 26. See also above, note 3 .

10 Ynguientes. Ynguënte is a variant of unguënto, as documented by Corominas, IV, p. 650a. In Celestina 1499?, vnguëntos occurs twice: "Entra en la camara de los vnguentos y en la pelleja del gato negro donde te mande meter los ojos de la loba le fallaras." (f. $c^{8} v, 1.10$ ) and "enuistiendolas en diuersos matizes: con vnguentos y unturas" ( $\left.f . f^{3} r, 1.11\right)$.

11 Siguros. Lapesa, p. 280, notes: "había vacilaciones de vocalismo (Sofrir, deferir, joventud, mochacho, cevil) que penetran hasta muy avanzado el período clásico."

12 Cátreda, catredático. Variants of cátedra and catedrático due to metathesis. Similar phenomena, such as craba for cabra, are cited by Lapesa, p. 494. The use of cátreda and catredático here seems to be allusive to academic life in Salamanca, and to provide metaphors for Selestina's arrest, conviction, and punishment by the civil authorities or the practice of the magic arts. The cátedra of Selestina is Magic; the justice voting for her recalls the Salamanca tradition of electing the professors to their posts and refers to her arrest and conviction. The executloner carrying out the vote or judgment parallels the formal investiture of a university chair and denotes Selestina's punishment by the law. The reference to going through the streets recalls the victory celebration where the winning candidate was enthusiastically greeted by his supporters, carried on their shoulders, and placed victoriously in his new chair. An account of such a celebration can be found in Gustave Reynier, La vie universitaire dans I'ancienne Espagne (Paris: A. Picard et fils, 1902), p. 79. Thus, Selestina employs academic vocabulary to refer to her illegal activities and punishments. 
13 Mormoráis. Even though in the sixteenth century the vacillation of unaccented vowels was diminishing, variation between $e$ and $i$ and 0 and $u$ was still rather common. As Lapesa, p. 368, notes, Santa Teresa writes mormorar for murmurar.

14 Sicutólo. Again, a vacillation of stem vowels: sicutó for secutó (esecutó). Lapesa 1ists other examples of this variation, e.g. mijor, siguir for mejor, seguir (p. 317). They are found in the prose of Santa-Teresa.

15 Ynoran. Ynoran represents the vulgar pronunciation and spelling of the Latinate consonant group gn. According to Lapesa, p. 390: "Todo el período áureo es época de lucha entre el respeto a la forma latina de los cultismos y la propensión a adaptarlos a los hábitos de la pronunciación romance. Valdés decía: 'quando escrivo para castellanos y entre castellanos quito siempre la $g$ y digo que la quito porque no la pronuncio." "

16 Gonzalo Correas, Vocabulario de refranes y frases proverbiales (1627) ed. Louis Combet (Bordeaux: Inst. d'Etudes Ibériques et Ibéro-Americaines, 1967), p. 512a, cites the proverb to which this one is related as: "Tres kada día i tres kada vez." The same proverb, although not found in the Comedia de Calisto y Melibea, appears in the Tragicomedia, Act IX (cited in the introduction to this edition). toria."

17 Mi ystoria. Selestina refers here to Rojas' Ceiestina as her own "es-

18 Juyāis. A variant of huyāis. See above, notes 3 and 9.

29 Esparto. According to Sebastián de Covarrubias, Tesoro de Za Zengua castelzana o española (Madrid: Ed. Turner, facsimile ed. of the 1611 printing) p. 552a, esparto is "una mata que produze unas ciertas varitas sutiles y difícilesde romper, de que ay abundancia en nuestra España."

20 Bersige. The $g$ for $g u$ is common in the period. Since the $u$ was not pronounced, it was often not written. Cárcel de amor (Sevilla 1492), has page for pague (f. $\mathrm{B}^{3} \mathrm{v}$ ).

21 Dis. Diphthong reduction was not uncommon in monosyllabic numbers. In Cárcel de amor, we find, for example, diez spelled des in one instance (f. $\left.F^{4} \mathrm{v}\right)$

22 Norabuena. Used also at 1ine 73. A variant of "enhorabuena" (Correas, p. 664a).

23 Rrecuero. Dicc. Aut. V, p. 527b, defines recuero as "el harriero, ò aquel à cuyo cargo está lá recua. Trahe esta voz Covarr. en la voz Récua.Lat. Mulio. Agaso." The phrase, "nunca llega tu rrecuero," appears to be a saying similar to "your ship never comes in." 
24 Fieros. The word fieros as an adjective or noun does not seem to fit the context of the sentence. As a verb, I can find no register of $f i$ $e r+o s$; it seems to be a form of fiar, the French form of which is fier. Dicc. Aut. III, p. 743a, defines fiar (transitive): "Assegurar que otro cumplirá lo que promete, ò pagará lo que debe, obligándose, en caso que no pague, à pagar por él. Lat. Fideiubere. Vadem pro aliquo fieri. (. . .) CERV, Nov. 8, p1. 24. Oyendo decir à Avendaño que él fiaba á su conpañero, dixo etc." Thus, Selestina seems to be saying that her door is not open to the student since she knows how to--or how not to--trust him and assure his payment before he enters. Also, regarding os, the Entremes uses both the $t \bar{u}$ and voseo for the second person singular form. The coexistence of the two in the same text is common.

25 Us. Both os and us spellings appear in our text. Lapesa, at page 471 , notes that many times unaccented $/ 0 /$ becomes $/ \mathrm{u} /$. Especially could there be analogy between os / us and the variants vos / vus.

26 Cus (cuz). According to Dicc. Aut., II, p. 713a, cuz is "nombre con que regularmente se 1 lama à los perros para darles de comer, que oy se suele decir Tus, tus. A perro viejo nunca cuz, cuz. Refr. que dá à entender que al que tiene práctica y experiencia de las cosas, no es facil engañarle con los agasajos ò apariencia de utilidad. Lat. Canem vetustum neutiquem dolis falles." Also, in Correas, p. 22b: "A perro viexo no tus tus; o no kuz kuz; a nunca kuz kuz. Ke no se dexa engañar komo el nuevo kon halagos i pan." And the same refrán is found in Celestina, 1499?, as we11: "a. perro viejo no cuz cuz" (f. $k^{7} r, 1.19$ ). Thus, "cus que no va n1 viene" seems to be a phrase similar to the refrán: "a cuz ni va ni viene el perro." That is, the person is not taken in by deception nor convinced by threats.

\section{Sin'os. For manuscript sinos, synaloepha for sino + os.}

28 Vna. Vna would refer to "burla" or some other similar feminine word. The sentence has no direct antecedent. Not discouraged by Selestina's refusal to admit him to the house, the student threatens her. He will have his own way, through trickery and deception.

29 Estodiante. An example of the variation of $o$ and $u$. See note 13 .

30 Dis (diz). An archaic form of dice (cf. Lapesa, p. 258). It was also used impersonally. According to H. Keniston, The Syntax of Castilian Prose (Chicago: Univ, of Chicago Press, 1937), p. 344: "the construction of diz que, equivalent to se dice que, is diminishing in the sixteenth century; of the 11 counted examples, only 2 are found in the second half of the century."

31 Espetar. According to Dicc. Aut., III, p. 601a-b, espetar "vale también passar de parte à parte à uno con la espada, ò meterla profundamente dentro del cuerpo." Or, as a reflexive, "ponerse mui tiesso y de- 
recho, afectando gravedad y soberania, y presumiendo ser persona de autoridad." The first of these seems to be the appropriate meaning for the context, referring figuratively to sexual intercourse.

32 Pelar. According to Covarrubias, p. 859a, pelar means "comerle a uno su hazienda, como hazen las rameras que pelan a los mancebos." Dicc. Aut., V, P. $189 \mathrm{~b}$, adds that "metaphoricamente vale quitar con engaño, arte ò violencia, los bienes à otro. Lat. Aliquem denudare. TORR. Philos. 1ib. 17. cap. 6. $\mathrm{Y}$ al fin quedar pelado, destruido, hambriento y con el exectór de la necessidad à la puerta. JACINT. POL. pl. 230. Y si acáso las come (perdices) es de los que entran en su casa y los pelan: pues quantos entraron con mas plumas que un juego de cañas, y luego salen de perros chinos?"

33 Vent. The relaxation of intervocalic and final /d/ was common in the spoken speech of the period. Other examples in our text appear at 11. 71, 77 and 82. See Lapesa, p. 389, note 59, for earlier examples.

34 Lorenso. The name here is used to refer to the bobo. Ealier, at 1. 44, he is called Lucas. There seems to be a confusion in the text.

35 Dorabuena. A variant of dehorabuena. Norabuena, a similar expression, is also used in the text, at lines 29 and 73.

36 Esdropelia. I. can find no register of this word in Castilian vocabularies of the period or of its antecedents in lexicons of medieval Latin or Roman law. It seems to be a term referring to a legal document such as a summons or an eviction notice. It could be derived from Lat. extra ('outside') + pello ('to push, propel').

37 Sale. Verb singular, with compound subject, a structure common to spoken language. See line 73 for another example.

38 Cubijada, cubixar. See also note 25, above. Lapesa, p. 368, cites other examples of this $0 / u$ vacillation: abondar, cobrir, roido.

39

Dacá mi manto. The phrase is used twice (also at line 67), and is found also in Celestina 1499?: "Ce. elicia elicia leuanta te dessa cama, daca mi manto presto" ( $f . \mathrm{k}^{7} \mathrm{r}$, line 29).

40 Come. For como.

41 Guardaldo. The variant of guardadzo resulting from metathesis.

42 This stage direction is crossed out in the manuscript.<smiles>[C]=C=C</smiles> 
In the reading edition I have modernized the accents, punctuation, word division and capitalization as in the transcription. In addition, I have modernized the use of $b, u, v ; i, y$; and initial $r$ and $r r$. I have also included the orthographic $h$, which helps distinguish between such homonyms as he and $e$. Synaloepha has been resolved (quel=que el, etc.) as well as all abbreviations used in the text. In all else, the original has been reproduced exactly.

\section{PRIMER ENTREMES DE SELESTINA}

\section{[ Dos damas, un villano, un alguazil, un corchete]}

Selestina: Ya hihas de mi alma, si mi demasiada edad no os haze deconoserme, me tendréls conosida y por sino lo soy. Yo soy aquella que di lus

5 a primas y a terseras: a primas de aprovechamiento, a terseras de la consonansia que han de hazer entre la prima y la parte para dar provecho y no quedar sin paga. Y soy aquella que en esta vida ha serrado cuatrosientios $y$ seis portillos que por contrarios han sido enalmagrados. Y soy aquella que a chupaderas que el vulgo llama bruhas ha dado

10 ynguëntes $y$ unsiones sufisientes a su arte. Y soy aquella de quien amantes ausentes no han vivido siguros de verse con sus damas traídos de lexas tierras en breve espasio mediante el arte del hechizo, de cuya abilidad he llevado cátreda tres veses. Ya sé 1o que mormuráis: diréis ahora que la justisia votó por mí y el verdugo sicutólo votada,

15 pues esas cátredas quiere que el catredátı́co, si no sale por la calle, cuatro lo saben $\mathrm{y}$ ocho lo inoran. Y soy querida de damas y galanes. Soy lus y lunbre del beber porque tanto valen tres vezes de vino como tres años de estudio, como en mi historia más largamente se lee. Sobre todo soy amiga de no estar sin tributo porque después que de mío

20 lo perdí, me arrimo a dos niñas que me lo dan conforme al que pide. Tengo en mis niñas toda mercaduría: al que pide donzella, se la doy donzella; y al que casada, la doy cazada; y viuda, al que viuda quiere. Huyo de estudiantes porque soy natural de Salamanca y conóscolos desde mi niñés, y sólo os encarga bobas. Que juyáis de ellos que son ave de rapiña, secos como esparto, pues con conosellos yo no me puedo librar de uno que me persige una de mis niñas y la tiene engañada con billetes en copla y ramilletes de a dis maravedís. iDesventurada yo!, que aun aquí no me puedo librar de él.

[Sale el estudiante.]

Estudiante: Norabuena vea yo a mi madre.

Selestina: ¿Yo tu madre? ¿Cuándo te parí?

Estudiante: Que todavia me eres contraria.

Selestina: Que todavía no tienes dineros; nunca llega tu recuero. Sierra esa puerta.

Estudiante: ¿No es cosa del diablo ésta que para todos esté tu puerta 35 abierta; y para mí solo serrada, pues por vida de quien soy? 
Selestina: No, como sé fieros.

[Vase]

Estudiante: Us vais y cus que no va ni viene que no seré yo el lisensiado Lidon si no os hago una que se ponga en el libro de 40 la fama ansí, señora Selestina.

[Sale el villano.]

Bobo: Que os digo, estudiante, que dis mi ama que os vais a espetar a donde os pelaron, que acá no hay espetadero.

Estudiante: ¡O hermano Lucas, seáis bienvenido! Abrásame.

Bobo: No, no. iAparta!', que oléis a pobre.

Estudiante: ¿No es cosa del diablo ésta que todos los de esta casa están fundados sobre interés?

Bobo: : Nọ; no, a Inés no la veréis, más aporreándola quedan.

Estudiante: ¡Aporreando! Vení acá, Lorenso. Son éstos dineros.

[Una mano con otra haze que suena dineros.]

Bobo: Sí, par Dios, dineros son. ¡Señora! ¡Señora!

Estudiante: ¡No! No la llaméis, que yo no los quiero sino para vos, si hazéis lo que us diré.

Bobo: Como vos me los déis, yo treparé.

Estudiante: Pues, mira que os atan fásil. Con sólo que le déis esta sédula a vuestra ama y ésta a doña María, os daré este dinero.

Bobo: $\quad Y$ a Inés, ino le he de dar nada?

Estudiante: No, a Inés, no. Ni aun ha de ver éstas.

Bobo: Dorabuena: una a mi ama y otra a doña María. Aguarda. [Vase.]

Estudiante: Esto va bueno. Bien mi vengansa se enderesa que 10 que éste lleva es una esdropelia que el que la tuviere no parará hora ni momento en casa. Y una ves está fuera, yo podré gozar de la mercaduría mejor que ésta vende.

¿Sale Selestina, el manto cubijada, y doña María, con el manto que se quiere cubixar y nunca asierta, disiendo:]

Selestina: Dacá mi manto.

María: No puedo estar enserrada tanto.

Selestina: Dacá mi manto.

María:- No puedo estar enserrada tanto.

Estudiante: Bueno va esto; vengándome vo.

[Sale el bobo.] 
Bobo:

¿Qué es esto? Sosegá. Serrado está. Ve ahí su manto.

[Sale la otra dama que es Inés.]

Inés: Mi lisensiado, norabuena te vea yo. iQué es esto que tiene $\mathrm{mi}$ madre y mi hermana?

Estudiante: No es nada, mi bien. Que es una esdropelia que he hecho para que tu madre no me estorbe el verte.

Bobo: Sosegá, diablos: estáis borrachas.

Inês: Pues, ¿cóme [sic] se puede quitar esto?

Estudiante: Con sólo quitalles aquel papel que tienen en la mano.

Inés: Pués si es tan fásil, ven; merendaremos entretanto.

Bobo: Que le digo, deme aquel dinero.

Estudiante: Que me plaze, mas primero quiero que me guardéis esta puerta." Tené estos papeles en la mano, y éste; guardaldo aquí en el pecho, que luego salgo.

[Vanse con la dama.]
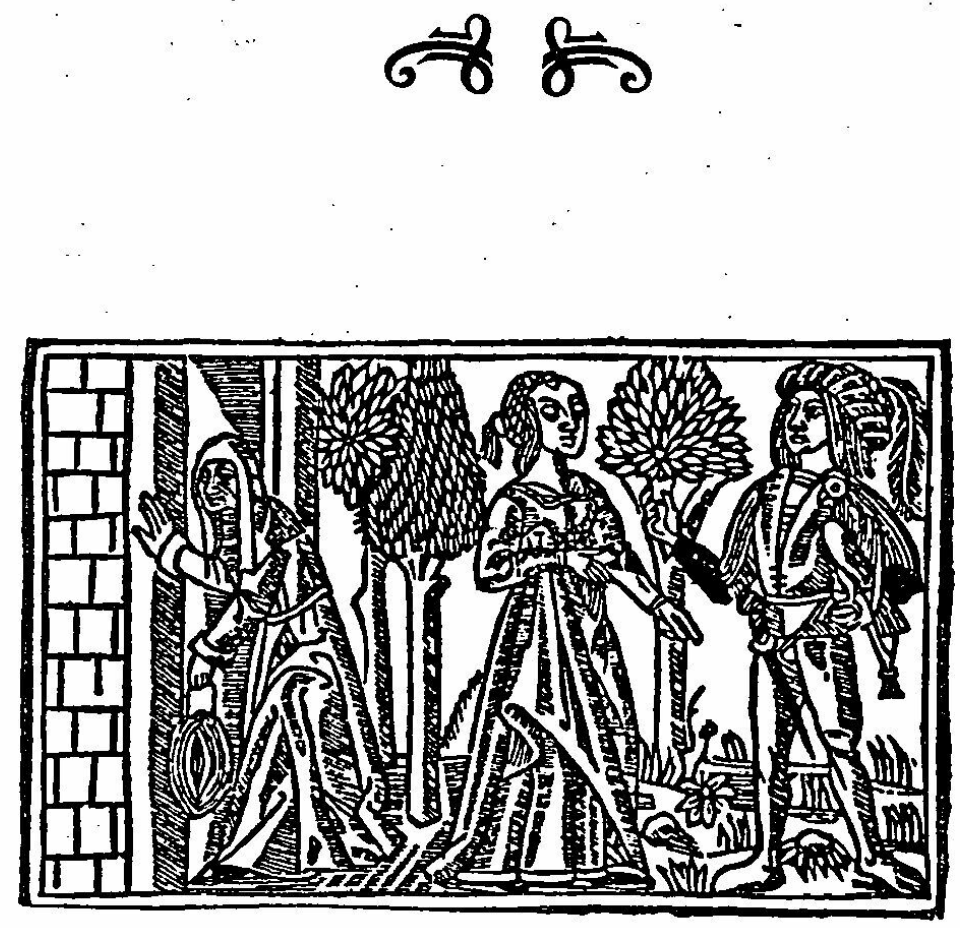

Eortada de la edicion Toledo 1500 (detalze) 


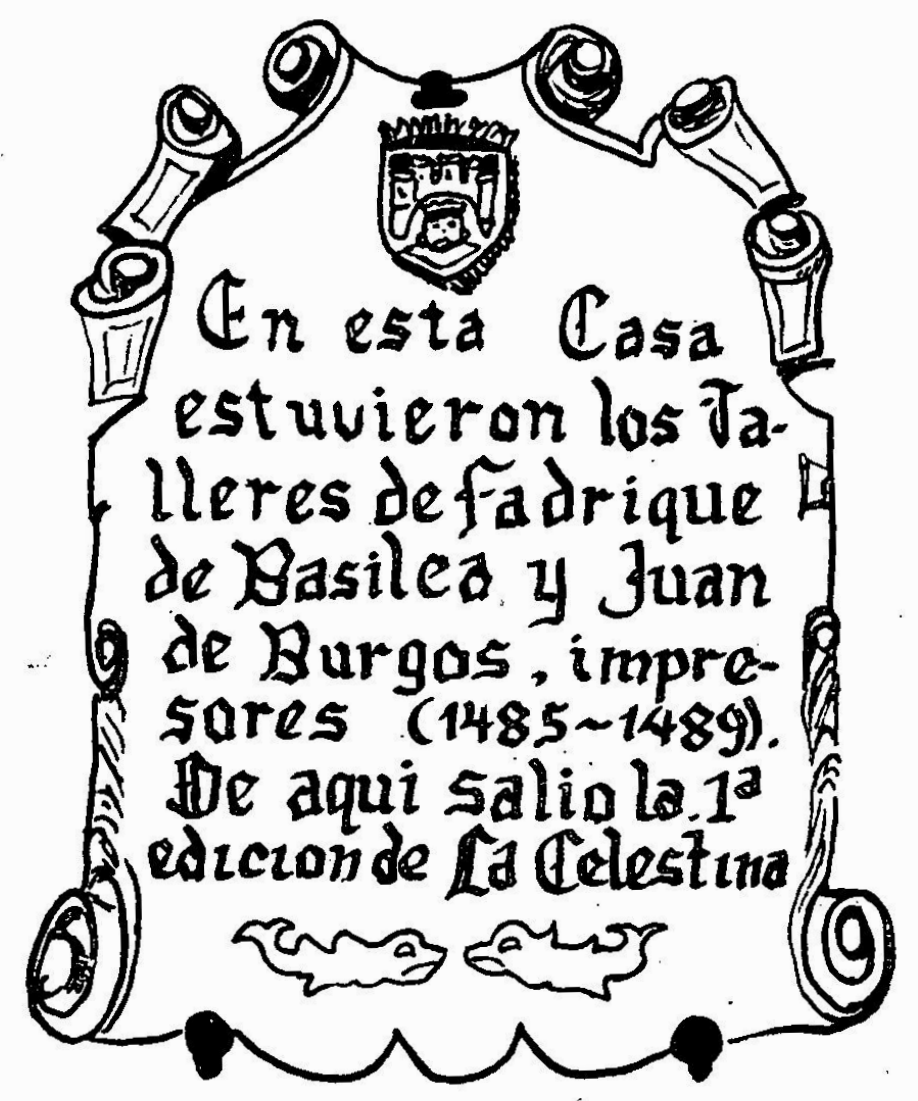

PLAQUE adorning the facade of the MESON DEL CID (BURGOS) 